Research report

\title{
GABAergic mechanisms of the lateral parabrachial nucleus on sodium appetite
}

\author{
Lisandra B. de Oliveira ${ }^{a}$, João C. Callera ${ }^{b}$, Laurival A. De Luca Jr. ${ }^{\text {, }}$, \\ Débora S.A. Colombari ${ }^{a}$, José V. Menani ${ }^{\text {a,* }}$ \\ ${ }^{a}$ Department of Physiology and Pathology, School of Dentistry, UNESP, Rua Humaitá 1680, 14801-903 Araraquara, SP, Brazil \\ ${ }^{\mathrm{b}}$ Department of Basic Sciences, School of Dentistry, UNESP, Araçatuba, SP, Brazil
}

Received 31 October 2006; received in revised form 25 February 2007; accepted 14 March 2007

Available online 3 April 2007

\begin{abstract}
GABAergic activation in the lateral parabrachial nucleus (LPBN) induces sodium and water intake in satiated and normovolemic rats. In the present study we investigated the effects of $\mathrm{GABA}_{\mathrm{A}}$ receptor activation in the $\mathrm{LPBN}$ on $0.3 \mathrm{M} \mathrm{NaCl}$, water, $2 \%$ sucrose and food intake in rats submitted to sodium depletion (treatment with the diuretic furosemide subcutaneously + sodium deficient food for $24 \mathrm{~h}$ ), $24 \mathrm{~h}$ food deprivation or $24 \mathrm{~h}$ water deprivation. Male Holtzman rats with bilateral stainless steel cannulas implanted into the LPBN were used. In sodium depleted rats, muscimol $\left(\mathrm{GABA}_{\mathrm{A}}\right.$ receptor agonist, $\left.0.5 \mathrm{nmol} / 0.2 \mu \mathrm{l}\right)$, bilaterally injected into the LPBN, produced an inconsistent increase of water intake and two opposite effects on $0.3 \mathrm{M} \mathrm{NaCl}$ intake: an early inhibition $(4.3 \pm 2.7$ versus saline: $14.4 \pm 1.0 \mathrm{ml} / 15 \mathrm{~min})$ and a late facilitation $(37.6 \pm 2.7$ versus saline: $21.1 \pm 0.9 \mathrm{ml} / 180 \mathrm{~min})$. The pretreatment of the LPBN with bicuculline $\left(\mathrm{GABA}_{\mathrm{A}}\right.$ receptor antagonist, $\left.1.6 \mathrm{nmol}\right)$ abolished these effects of muscimol. Muscimol into the LPBN also reduced food deprivation-induced food intake in the first $30 \mathrm{~min}$ of test $(1.7 \pm 0.6 \mathrm{~g}$ versus saline: $4.1 \pm 0.6 \mathrm{~g}$ ), without changing water deprivation-induced water intake or $2 \%$ sucrose intake in sodium depleted rats. Therefore, although $\mathrm{GABA}_{\mathrm{A}}$ receptors in the LPBN are not tonically involved in the control of sodium depletion-induced sodium intake, $\mathrm{GABA}_{\mathrm{A}}$ receptor activation

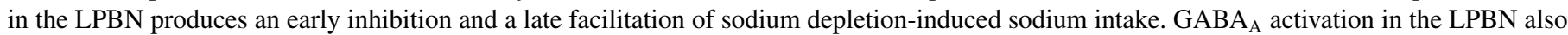
inhibits food intake, while it consistently increases only sodium intake and not water, food or sucrose intake.
\end{abstract}

(C) 2007 Elsevier Inc. All rights reserved.

Keywords: Sodium depletion; Sodium intake; Thirst; Food intake; Sucrose intake; Muscimol

\section{Introduction}

The inhibitory neurotransmitter $\gamma$-aminobutyric acid (GABA) is widely distributed through the central nervous system binding to two receptor subtypes: $\mathrm{GABA}_{\mathrm{A}}$ and $\mathrm{GABA}_{\mathrm{B}}$ $[9,26,7,6,3]$.

Studies have shown different effects of GABAergic mechanisms on ingestive behaviors depending on the central area tested. Injections of muscimol $\left(\mathrm{GABA}_{\mathrm{A}}\right.$ receptor agonist) or baclofen $\left(\mathrm{GABA}_{\mathrm{B}}\right.$ receptor agonist) into the nucleus accumbens shell of rats induced food and sucrose intake without affecting water, saline or saccharin intake $[4,39]$. However, injected into

\footnotetext{
* Corresponding author. Tel.: +55 163301 6486; fax: +55 1633016488 .

E-mail address: menani@foar.unesp.br (J.V. Menani).
}

the central nucleus of amygdala, muscimol reduced food intake in rats [32] and injected into the median and dorsal raphe nucleus or into the ventral tegmental area induced water intake in satiated rats $[23,24]$. Muscimol or GABA injected intracerebroventricularly (icv) and/or into the preoptic area reduced the dipsogenic effects of angiotensin II (ANG II) or carbachol (cholinergic agonist) and water and salt intake induced by central injection of renin $[1,44]$. Additionally, in food-deprived animals, the sight and ingestion of food increase the release of GABA in the zone incerta. The same occurs in sodium-depleted animals by the sight and ingestion of salt solutions [21].

Recent studies have shown important mechanisms to control sodium and water intake in the lateral parabrachial nucleus (LPBN), a pontine structure localized dorsolaterally to the superior cerebellar penducle [10,8,11,30,28,29,31,27,12,34]. Lesions of the LPBN increase water intake induced by ANG II 
[33]. Bilateral injections of the serotonergic antagonist methysergide into the LPBN strongly increases water and hypertonic sodium chloride $(\mathrm{NaCl})$ intake induced by $24 \mathrm{~h}$ sodium depletion, deoxicorticosterone (DOCA) or treatment with the diuretic furosemide combined with a low dose of the angiotensin converting enzyme inhibitor captopril, while injections of the

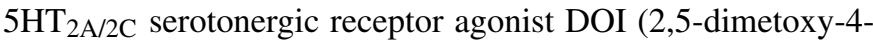
iodoamphetamine hydrobromide) into the LPBN reduce water and $\mathrm{NaCl}$ intake induced by DOCA or furosemide + captopril [11,29,31]. A recent study has also shown that activation of $\mathrm{GABA}_{\mathrm{A}}$ receptors by bilateral injections of muscimol into the LPBN induces a large $0.3 \mathrm{M} \mathrm{NaCl}$ intake and also a slight ingestion of water in satiated and normovolemic rats [8]. Additionally, the activation of serotonergic $5 \mathrm{HT}_{1 \mathrm{~B}}$ receptors into the LPBN reduced food intake $[37,25]$, while midazolam (benzodiazepine receptor agonist) into the parabrachial nucleus (PBN) increased food intake [38]. Moreover, voluntary sucrose intake induced c-fos protein (a neuronal activity marker) production into the medial and lateral PBN in rats [40].

A dense plexus of GABA-immunoreactive varicosities have been shown throughout the PBN and Kolliker Fuse (KF) complex and different subunits of $\mathrm{GABA}_{\mathrm{A}}$ receptors are differently distributed along PBN/KF complex [15]. It was also already shown the presence of $\mathrm{GABA}_{\mathrm{A}}$ receptors in the LPBN $[3,17,35]$.

Although a previous study has already shown that activation of $\mathrm{GABA}_{\mathrm{A}}$ receptors into the LPBN induces sodium and water intake in satiated rats [8], the possible effects of $\mathrm{GABA}_{\mathrm{A}}$ receptor activation in the LPBN on sodium depletion-induced $\mathrm{NaCl}$ intake and on sucrose and food intake have not been tested yet. Therefore, in the present study, we investigated the effects of $\mathrm{GABA}_{\mathrm{A}}$ receptor activation in the LPBN on water, $0.3 \mathrm{M} \mathrm{NaCl}$ and $2 \%$ sucrose intake in $24 \mathrm{~h}$ sodium depleted rats, water intake in $24 \mathrm{~h}$ water deprived rats and food, water and $0.3 \mathrm{M} \mathrm{NaCl}$ intake in $24 \mathrm{~h}$ food deprived rats.

\section{Material and methods}

\subsection{Animals}

Male Holtzman rats weighing $300-320 \mathrm{~g}$ were used. The animals were housed in individual stainless steel cages with free access to normal sodium diet (Guabi Rat Chow, Paulinia, SP, Brazil) and water. Free access to $0.3 \mathrm{M}$ $\mathrm{NaCl}$ or $2 \%$ sucrose solution was allowed for rats that had the ingestion of these solutions tested. Room temperature was maintained at $23 \pm 2{ }^{\circ} \mathrm{C}$, and humidity at $55 \pm 10 \%$ on a 12:12 light-dark cycle with light onset at 07:30 a.m. The Ethical Committee for Animal Care and Use from Dentistry School of Araraquara UNESP approved the experimental protocols used in the present study.

\subsection{Cerebral cannulas}

Rats were anesthetized with subcutaneous (sc) injection of ketamine ( $80 \mathrm{mg} / \mathrm{kg}$ of body weight) combined with xylazine $(7 \mathrm{mg} / \mathrm{kg}$ of body weight) and placed in a Kopf stereotaxic instrument. The skull was leveled between bregma and lambda. Stainless steel 23 -gauge cannulas were implanted bilaterally into the LPBN using the following coordinates: $9.4 \mathrm{~mm}$ caudal to bregma, $2.2 \mathrm{~mm}$ lateral to the midline, and $4.3 \mathrm{~mm}$ below the dura mater. The tips of the cannulas were positioned at a point $2 \mathrm{~mm}$ above each LPBN. The cannulas were fixed to the cranium using dental acrylic resin and watch screws. Metal obturators (30-gauge) filled the cannulas between tests. After the surgery, the rats were allowed to recover for 5 days before starting ingestion tests.

\subsection{Injections into the $L P B N$}

Bilateral injections into the LPBN were made using 5- $\mu 1$ Hamilton syringes connected by polyethylene tubing (PE-10) to 30 -gauge injection cannulas. At the time of testing, obturators were removed and the injection cannula ( $2 \mathrm{~mm}$ longer than the guide cannula) was carefully inserted into the guide cannula, and manual injection was initiated approximately $20 \mathrm{~s}$ later. For bilateral injections, the first injection was initially performed in one side, the needle was withdrawn and repositioned in the contra-lateral side, and then the second injection was made. Therefore injections were made $\sim 1 \mathrm{~min}$ apart. The injection volume into the LPBN was $0.2 \mu l$ in each site. The obturators were replaced after the injections, and the rats were placed back into their cage.

\subsection{Drugs}

Furosemide (Sigma Chem., St. Louis, MO, USA) was administered sc at $20 \mathrm{mg} / \mathrm{kg}$ of body weight. The drugs injected into the LPBN were muscimol $\mathrm{HBr}$ purchased from Research Biochemicals Internationals (RBI, Natick, MA, USA) and bicuculline and CGP 35348 purchased from Tocris (Ellisville, MO, USA). Muscimol $\mathrm{HBr}\left(\mathrm{GABA}_{\mathrm{A}}\right.$ receptor agonist) and CGP $35348\left(\mathrm{GABA}_{\mathrm{B}}\right.$ receptor antagonist) were dissolved in saline and bicuculline $\left(\mathrm{GABA}_{\mathrm{A}}\right.$ receptor antagonist) was dissolved in a mix of propylene glycol/water 2:1 (vehicle).

The doses of muscimol $(0.5 \mathrm{nmol} / 0.2 \mu \mathrm{l})$ and bicuculline $(1.6 \mathrm{nmol} / 0.2 \mu \mathrm{l})$ were based on previous study [8]. The dose of CGP $35348(50 \mathrm{nmol} / 0.2 \mu \mathrm{l})$ was based on preliminary results that showed that CGP 35348 at this dose abolished the effects of $\mathrm{GABA}_{\mathrm{B}}$ receptor agonist (baclofen) on sodium intake in satiated and normovolemic rats, so CGP 35348 was used in a dose enough to abolish the effects of its agonist.

\subsection{Sodium and water intake in $24 \mathrm{~h}$ sodium depleted rats}

Besides water and food pellets, rats had access to $0.3 \mathrm{M} \mathrm{NaCl}$ for at least 5 days before the beginning of the experiments. One day before the tests, rats were treated with sc furosemide $(20 \mathrm{mg} / \mathrm{kg}$ of body weight) and maintained for $24 \mathrm{~h}$ with sodium deficient food (powdered corn meal, $0.001 \%$ sodium, $0.33 \%$ potassium) and water. Twenty-four hours after furosemide, water and sodium deficient food were removed from the cage, rats received bilateral injections of muscimol $(0.5 \mathrm{nmol} / 0.2 \mu \mathrm{l})$ or saline into the LPBN and $15 \mathrm{~min}$ later had access to water and $0.3 \mathrm{M} \mathrm{NaCl}$, (2-bottle test), but not food. Rats were tested in their home cages. Water and $0.3 \mathrm{M} \mathrm{NaCl}$ were provided from burettes with $0.1-\mathrm{ml}$ divisions that were fitted with metal drinking spouts

\subsection{Sodium, water and food intake in $24 \mathrm{~h}$ food-deprived rats}

Besides water and food pellets, rats had access to $0.3 \mathrm{M} \mathrm{NaCl}$ for at least 5 days before the beginning of the experiments. Rats had food removed, but water and $0.3 \mathrm{M} \mathrm{NaCl}$ available for $24 \mathrm{~h}$. After this period, the burettes with water and $0.3 \mathrm{M} \mathrm{NaCl}$ were removed and the animals received bilateral injections of muscimol $(0.5 \mathrm{nmol} / 0.2 \mu \mathrm{l})$ or saline into the LPBN. Fifteen minutes after the injections into the LPBN, the animals had free access to water, $0.3 \mathrm{M} \mathrm{NaCl}$ and a pre-weighted amount of regular chow pellets. Cumulative water, $0.3 \mathrm{M} \mathrm{NaCl}$ and food intakes were measured at every $30 \mathrm{~min}$ during $240 \mathrm{~min}$. All the chow spillage under the cages was recovered at every measurement to calculate food intake.

\subsection{Water intake in $24 \mathrm{~h}$ water deprived rats}

Rats had water removed, but food available for $24 \mathrm{~h}$. After this period, food was removed and the animals received bilateral injections of muscimol $(0.5 \mathrm{nmol} / 0.2 \mu \mathrm{l})$ or saline into the LPBN. Fifteen minutes after the injections into the LPBN, the animals had free access to graduated burettes with water. Cumulative water intake was measured at $15 \mathrm{~min}$ and after every 30 min during 240 min. 


\subsection{Sodium, water and $2 \%$ sucrose intake in $24 \mathrm{~h}$ sodium depleted rats}

To test the specificity of the effects of muscimol into the LPBN on sodium and water intake, besides water and $0.3 \mathrm{M} \mathrm{NaCl}$, one group of sodium depleted rats had also access to $2 \%$ sucrose.

Besides water and food pellets, rats had access to $0.3 \mathrm{M} \mathrm{NaCl}$ and $2 \%$ sucrose for at least 5 days before the beginning of the experiments. After 5 days, rats were treated with sc furosemide $(20 \mathrm{mg} / \mathrm{kg}$ of body weight) and maintained for $24 \mathrm{~h}$ with sodium deficient food (powdered corn meal, $0.001 \%$ sodium, $0.33 \%$ potassium) and water. After $24 \mathrm{~h}$, rats received bilateral injections of muscimol $(0.5 \mathrm{nmol} / 0.2 \mu \mathrm{l})$ or saline $(0.2 \mu \mathrm{l})$ into the LPBN and $15 \mathrm{~min}$ later had access to water, $0.3 \mathrm{M} \mathrm{NaCl}$ and $2 \%$ sucrose (3-bottle test). Cumulative water, $0.3 \mathrm{M} \mathrm{NaCl}$ and $2 \%$ sucrose intakes were measured at $15 \mathrm{~min}$ and after every $30 \mathrm{~min}$ during $180 \mathrm{~min}$.

\subsection{Histology}

At the end of the experiments, animals received bilateral injections of $2 \%$ Evans blue solution $(0.2 \mu \mathrm{l})$ into the LPBN. They were then deeply anesthetized with thiopental sodium $(80 \mathrm{mg} / \mathrm{kg}$ of body weight) and perfused transcardially with saline followed by $10 \%$ formalin. The brains were removed, fixed in $10 \%$ formalin, frozen, cut in $50-\mu \mathrm{m}$ serial coronal sections, stained with Giemsa, and analyzed by light microscopy to confirm the injection sites into the LPBN.

\subsection{Statistical analysis}

Results were analyzed for each interval of test $(0-15 \mathrm{~min}, 15-30 \mathrm{~min}$ and every $30 \mathrm{~min}$ until the end of the test that lasted $180-240 \mathrm{~min}$ ). The total intake during the whole period of test was also analyzed. The results are reported as means \pm S.E.M. The intake at the different intervals after different treatments was analyzed by two way repeated measures ANOVA and Fisher's LSD. One-way ANOVA or $t$-test were used to compare the total of ingestion after different treatments. Differences were considered significant at $p<0.05$.

\subsection{Experimental protocols}

\subsubsection{Effects of muscimol combined with bicuculline into the LPBN on}

$0.3 \mathrm{M} \mathrm{NaCl}$ and water intake in sodium depleted rats

To test the effects of the $\mathrm{GABA}_{\mathrm{A}}$ receptor agonist muscimol combined with the $\mathrm{GABA}_{\mathrm{A}}$ receptor antagonist bicuculline on sodium and water intake, $24 \mathrm{~h}$ sodium depleted rats received the following treatments into the LPBN: vehicle + saline, vehicle + muscimol, bicuculline + saline and bicuculline + muscimol. Water and $0.3 \mathrm{M} \mathrm{NaCl}$ intakes were measured at 15,30 , $60,90,120,150$ and $180 \mathrm{~min}$ after bilateral injections of muscimol or saline into the LPBN. In each test, the group of rats was divided in two and half of the group received one treatment into the LPBN and the remaining animals received another treatment into the LPBN. The sequence of the treatments into the LPBN in each rat in different tests was randomized and at the end of the experiments each rat received all the four treatments.

A recovery period of at least 3 days was allowed among tests.

One group of 43 naive rats was used to test the effects of the combination of muscimol and bicuculline into the LPBN on sodium and water intake and the histological analyses showed that 7 of these rats had bilateral injections correctly placed into the LPBN.

\subsubsection{Effects of muscimol combined with CGP 35348 into the LPBN on $0.3 \mathrm{M} \mathrm{NaCl}$ and water intake in sodium depleted rats}

To test the effects of muscimol combined with the $\mathrm{GABA}_{\mathrm{B}}$ receptor antagonist CGP 35348 on sodium and water intake, $24 \mathrm{~h}$ sodium depleted rats were submitted to the same protocol described above for the combination of muscimol and bicuculline, except that CGP 35348 was injected into the LPBN instead of bicuculline. A recovery period of at least 3 days was allowed among tests.
One group of 23 naïve rats was used to test the effects of the combination of muscimol and CGP 35348 into the LPBN on sodium and water intake and the histological analyses showed that 7 of these rats had bilateral injections correctly placed into the LPBN.

\subsubsection{Effects of muscimol into the LPBN on food, $0.3 \mathrm{M} \mathrm{NaCl}$ and water intake in $24 \mathrm{~h}$ food-deprived rats}

Rats that had food removed, but water and $0.3 \mathrm{M} \mathrm{NaCl}$ available for $24 \mathrm{~h}$, received bilateral injections of muscimol $(0.5 \mathrm{nmol} / 0.2 \mu \mathrm{l})$ or saline into the LPBN and $15 \mathrm{~min}$ later had access to water, $0.3 \mathrm{M} \mathrm{NaCl}$ and food. Water, $0.3 \mathrm{M} \mathrm{NaCl}$ and food intakes were measured at $30,60,90,120,150,180,210$ and $240 \mathrm{~min}$ after bilateral injections of muscimol or saline into the LPBN The group was submitted to two tests and in each test, the group of rats was divided in two. In the first test, half of the group received muscimol into the LPBN and the remaining animals received saline into the LPBN. In the next test the rats received the same treatments into the LPBN in a counterbalanced design. A recovery period of at least 3 days was allowed between the tests.

One group of 12 naïve rats was used to test the effects of muscimol into the LPBN on sodium, water and food intake and the histological analyses showed that 8 of these rats had bilateral injections correctly placed into the LPBN.

\subsubsection{Effects of muscimol into the LPBN on water intake in $24 \mathrm{~h}$ water-deprived rats}

Rats that had water removed from the cage $24 \mathrm{~h}$ before, received bilateral injections of muscimol $(0.5 \mathrm{nmol} / 0.2 \mu \mathrm{l})$ or saline into the LPBN and $15 \mathrm{~min}$ later had access to water. Water intake was measured at 15, 30, 60, 90, 120, 150, 180,210 and $240 \mathrm{~min}$ after bilateral injections of muscimol or saline into the LPBN. The group of rats was submitted to two tests and in each test, the group of rats was divided in two. In the first test, half of the group received muscimol into the LPBN and the remaining animals received saline into the LPBN. In the next test the rats received the same treatments into the LPBN in a counterbalanced design. A recovery period of at least 3 days was allowed between the tests.

One group of 23 naïve rats was used to test the effects of muscimol into the LPBN on water intake and the histological analyses showed that 9 of these rats had bilateral injections correctly placed into the LPBN.

\subsubsection{Effects of muscimol into the LPBN on sodium, water and $2 \%$ sucrose intake in sodium depleted rats}

Rats submitted to $24 \mathrm{~h}$ sodium depletion (furosemide + sodium deficient diet for $24 \mathrm{~h})$ received bilateral injections of muscimol $(0.5 \mathrm{nmol} / 0.2 \mu \mathrm{l})$ or saline into the LPBN. Water, $0.3 \mathrm{M} \mathrm{NaCl}$ and $2 \%$ sucrose intakes were measured at 15,30 , $60,90,120,150$ and $180 \mathrm{~min}$ after bilateral injections of muscimol or saline into the LPBN. The group of rats was submitted to two tests and in each test, the group of rats was divided in two. In the first test, half of the group received muscimol into the LPBN and the remaining animals received saline into the LPBN. In the next test the rats received the same treatments in a counterbalanced design.

A recovery period of at least 3 days was allowed between tests.

One group of 38 naïve rats was used to test the effects of muscimol into the LPBN on sodium, water and $2 \%$ sucrose intake and the histological analyses showed that 7 of these rats had bilateral injections correctly placed into the LPBN.

\section{Results}

\subsection{Histological analysis}

Fig. 1 shows the typical LPBN injection sites. Most of the injections were into the central lateral and dorsolateral portions of the LPBN (see [14] for definitions of LPBN subnuclei). Some of the injections reached the ventral lateral and external 


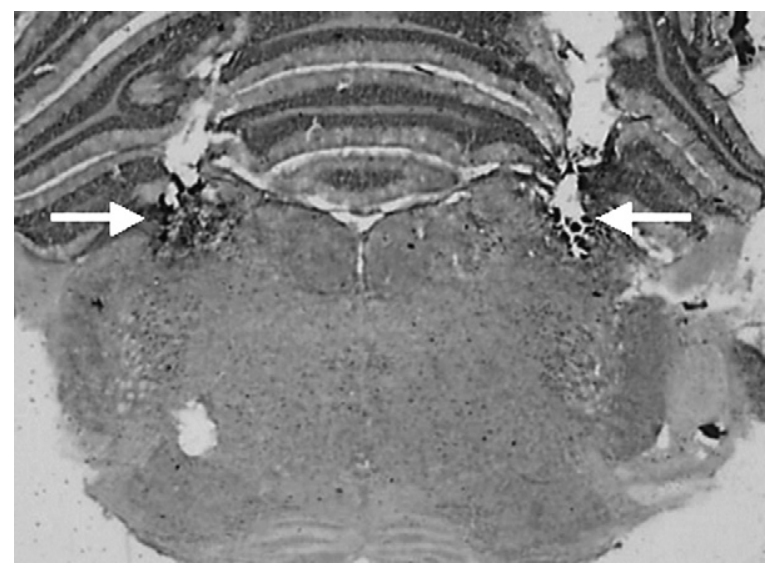

Fig. 1. Photomicrograph showing the sites of injections into the LPBN (arrows).

lateral portions, as well as the Kolliker-Fuse nucleus, and in some rats, injections also spread to the brachium (superior cerebellar peduncle), or slightly ventral to this structure, reaching the dorsal portions of the medial parabrachial nucleus
(MPBN) uni or bilaterally. There was no difference in the effects whether injections were restricted to the LPBN or also spread to brachium and dorsal portions of MPBN.

\subsubsection{Effects of bilateral injections of muscimol alone or combined with bicuculline or CGP 35348 into the LPBN on sodium depletion-induced $0.3 \mathrm{M} \mathrm{NaCl}$ intake}

Muscimol $(0.5 \mathrm{nmol} / 0.2 \mu \mathrm{l})$ injected bilaterally into the LPBN in $24 \mathrm{~h}$-sodium depleted rats produced two opposite effects on $0.3 \mathrm{M} \mathrm{NaCl}$ intake: an early inhibitory effect in the first $15 \mathrm{~min}$ of test and a facilitation of sodium intake from 30 to 120 min of test $[F(3,18)=7.1 ; p<0.005]$ (Fig. 2A). Simultaneously to changes in sodium intake, muscimol into the LPBN in $24 \mathrm{~h}$-sodium depleted rats, also increased water intake from 60 to $120 \mathrm{~min}$ of test $[F(3,18)=6.7 ; p<0.005]$ (Fig. $2 \mathrm{~B})$. The total intake of $0.3 \mathrm{M} \mathrm{NaCl}$ and water during the whole test increased after muscimol into the LPBN (Fig. 2C and D, respectively).

Previous injections of the $\mathrm{GABA}_{\mathrm{A}}$ antagonist bicuculline $(1.6 \mathrm{nmol} / 0.2 \mu \mathrm{l})$ into the LPBN abolished the effects of muscimol on sodium and water intake (Fig. 2).

$$
\begin{gathered}
-\square \text { vehicle + saline } \\
* \square \text { vehicle }+ \text { muscimol } \\
* \text { different from vehicle + saline } \\
(n=7)
\end{gathered}
$$
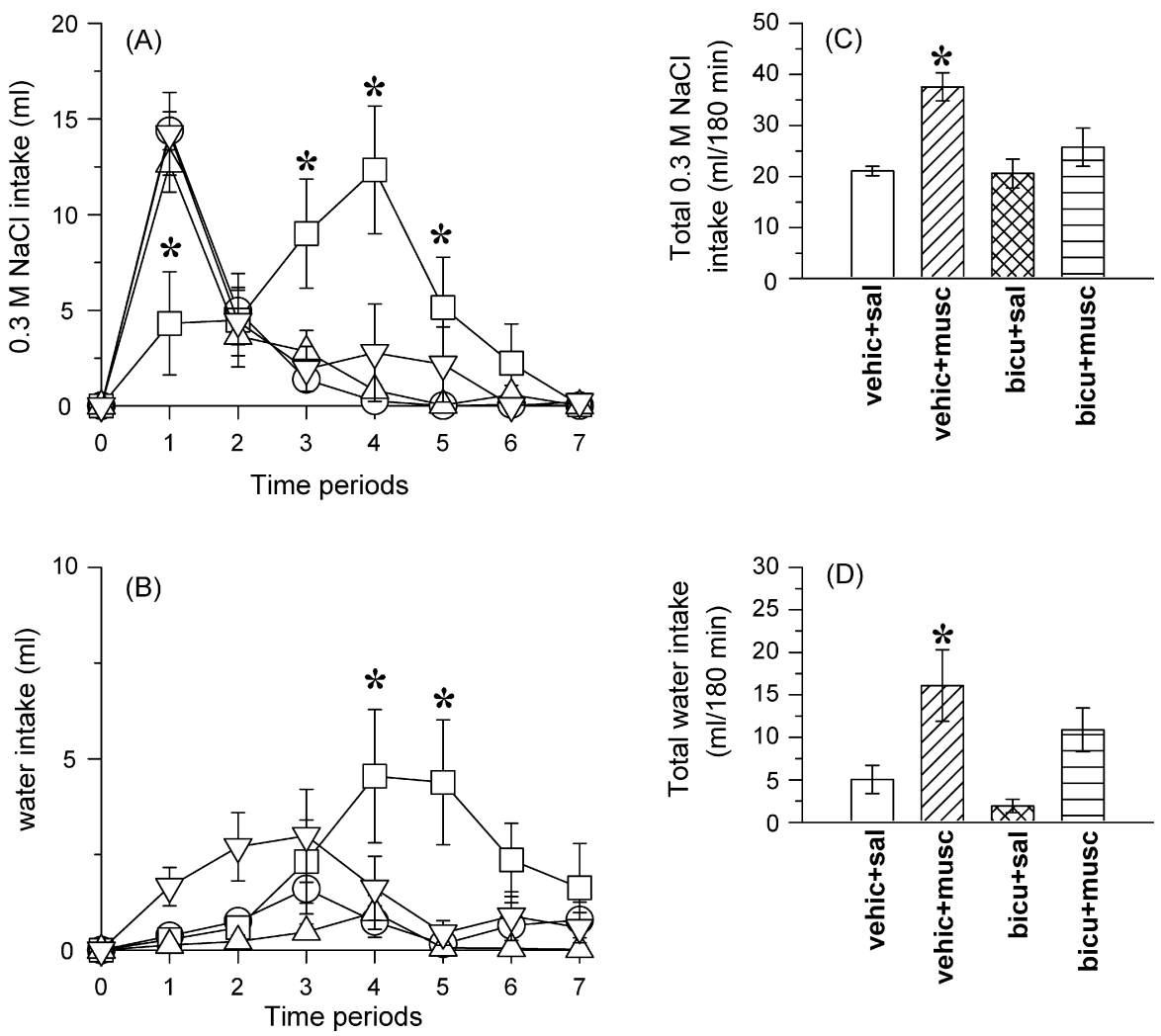

Fig. 2. Left panels: (A) $0.3 \mathrm{M} \mathrm{NaCl}$ and (B) water intake at different periods of test. Right panels: total (C) $0.3 \mathrm{M} \mathrm{NaCl}$ and (D) water intake during the whole test in $24 \mathrm{~h}$ sodium depleted rats that received bilateral injections of bicuculline $(1.6 \mathrm{nmol} / 0.2 \mu \mathrm{l})$ or vehicle combined with muscimol $(0.5 \mathrm{nmol} / 0.2 \mu \mathrm{l})$ or saline into the LPBN. Results are expressed as means \pm S.E.M.; $n$, number of rats; time periods: $1=0-15 \mathrm{~min}, 2=15-30 \mathrm{~min}, 3=30-60 \mathrm{~min}, 4=60-90 \mathrm{~min}, 5=90-120 \mathrm{~min}$, $6=120-150 \mathrm{~min}$ and $7=150-180 \mathrm{~min} ; \mathrm{sal}=$ saline musc $=$ muscimol; vehic $=$ vehicle bicu $=$ bicuculline . 

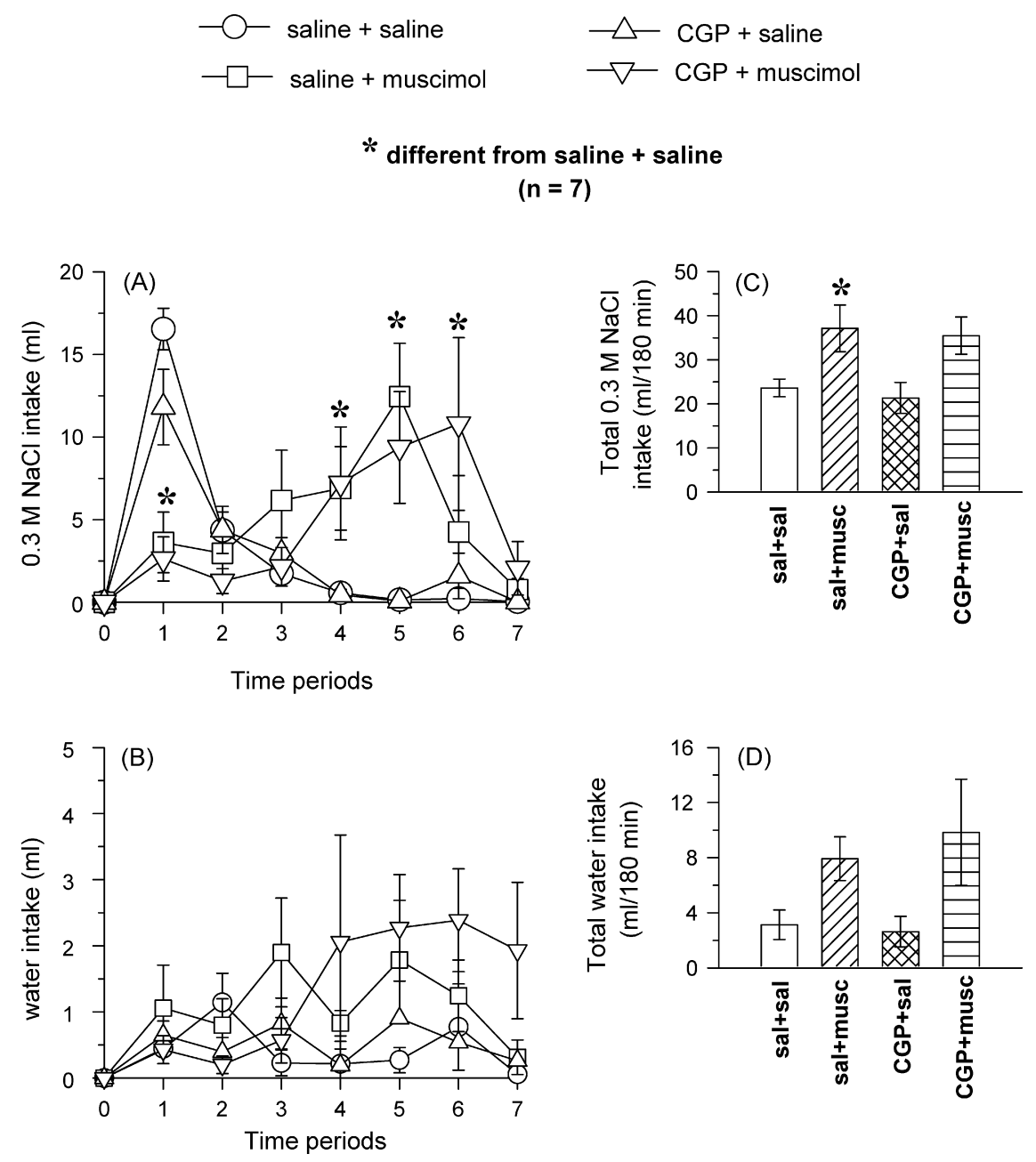

Fig. 3. Left panels: (A) $0.3 \mathrm{M} \mathrm{NaCl}$ and (B) water intake at different periods of test. Right panels: total (C) $0.3 \mathrm{M} \mathrm{NaCl}$ and (D) water intake during the whole test in $24 \mathrm{~h}$ sodium depleted rats that received bilateral injections of CGP $35348(50 \mathrm{nmol} / 0.2 \mu \mathrm{l})$ or saline combined with muscimol $(0.5 \mathrm{nmol} / 0.2 \mu \mathrm{l})$ or saline into the LPBN. Results are expressed as means \pm S.E.M.; $n$, number of rats; time periods: $1=0-15 \mathrm{~min}, 2=15-30 \mathrm{~min}, 3=30-60 \mathrm{~min}, 4=60-90 \mathrm{~min}, 5=90-120 \mathrm{~min}$, $6=120-150 \mathrm{~min}$ and $7=150-180 \mathrm{~min} ; \mathrm{sal}=$ saline; musc $=$ muscimol $;$ CGP $=$ CGP 35348.

The pretreatment with the $\mathrm{GABA}_{\mathrm{B}}$ receptor antagonist CGP $35348(50 \mathrm{nmol} / 0.2 \mu \mathrm{l})$ did not modify the inhibitory or the facilitatory effects of muscimol into the LPBN on $0.3 \mathrm{M} \mathrm{NaCl}$ intake $[F(3,18)=3.9 ; p<0.05]$ (Fig. $3 \mathrm{~A}$ and $\mathrm{C}$ ). In the group of rats treated with muscimol combined with CGP 35348 , water intake was not modified by muscimol into the $\operatorname{LPBN}[F(3,18)=2.3$; $p>0.05$ ] (Fig. 3B and D).

Bicuculline $(1.6 \mathrm{nmol} / 0.2 \mu \mathrm{l})$ or CGP $35348(50 \mathrm{nmol} / 0.2 \mu \mathrm{l})$ injected alone into the LPBN did not affect $0.3 \mathrm{M} \mathrm{NaCl}$ intake or water intake (Figs. 2 and 3).

\subsubsection{Effects of bilateral injections of muscimol into the $L P B N$ on water, $0.3 \mathrm{M} \mathrm{NaCl}$ and food intake by $24 \mathrm{~h}$ food deprivation}

In $24 \mathrm{~h}$ food deprived rats, muscimol $(0.5 \mathrm{nmol} / 0.2 \mu \mathrm{l})$ bilaterally injected into the LPBN induced $0.3 \mathrm{M} \mathrm{NaCl}$ intake in the last $2 \mathrm{~h}$ of test $[F(1,7)=7.0 ; p<0.05]$ (Fig. 4A), increased water intake in the last $30 \mathrm{~min}$ of test (Fig. 4B) and reduced food intake in the first $30 \mathrm{~min}$ of test (Fig. 4C). ANOVA showed significant interaction between treatments and times for water intake $[F(7,49)=2.5 ; p<0.05]$ (Fig. 4B) and food intake $[F(7,49)=4.0 ; p<0.005]$ (Fig. $4 C$ ). The total intake of $0.3 \mathrm{M} \mathrm{NaCl}$ increased after muscimol into the LPBN (Fig. 4D), without changing the total of water (Fig. 4E) and food ingested (Fig. 4F).

\subsubsection{Effects of bilateral injections of muscimol into the $L P B N$ on water intake by $24 \mathrm{~h}$ water deprivation}

Bilateral injections of muscimol $(0.5 \mathrm{nmol} / 0.2 \mu \mathrm{l})$ into the LPBN did not affect $24 \mathrm{~h}$ water deprivation-induced water intake $[F(1,8)=2.8, p>0.05]$ (Fig. 5).

\subsubsection{Effects of bilateral injections of muscimol into the $L P B N$ on water, $0.3 \mathrm{M} \mathrm{NaCl}$ and $2 \%$ sucrose intake in sodium depleted rats}

Bilateral injections of muscimol $(0.5 \mathrm{nmol} / 0.2 \mu \mathrm{l})$ into the LPBN in $24 \mathrm{~h}$ sodium-depleted rats that had access to $0.3 \mathrm{M}$ $\mathrm{NaCl}$, water and $2 \%$ sucrose simultaneously, reduced $0.3 \mathrm{M}$ $\mathrm{NaCl}$ intake in the first $15 \mathrm{~min}$, increased it from 30 to $90 \mathrm{~min}$ $[F(1,6)=10.4, p<0.05]$ (Fig. 6A) and had no effects on water 

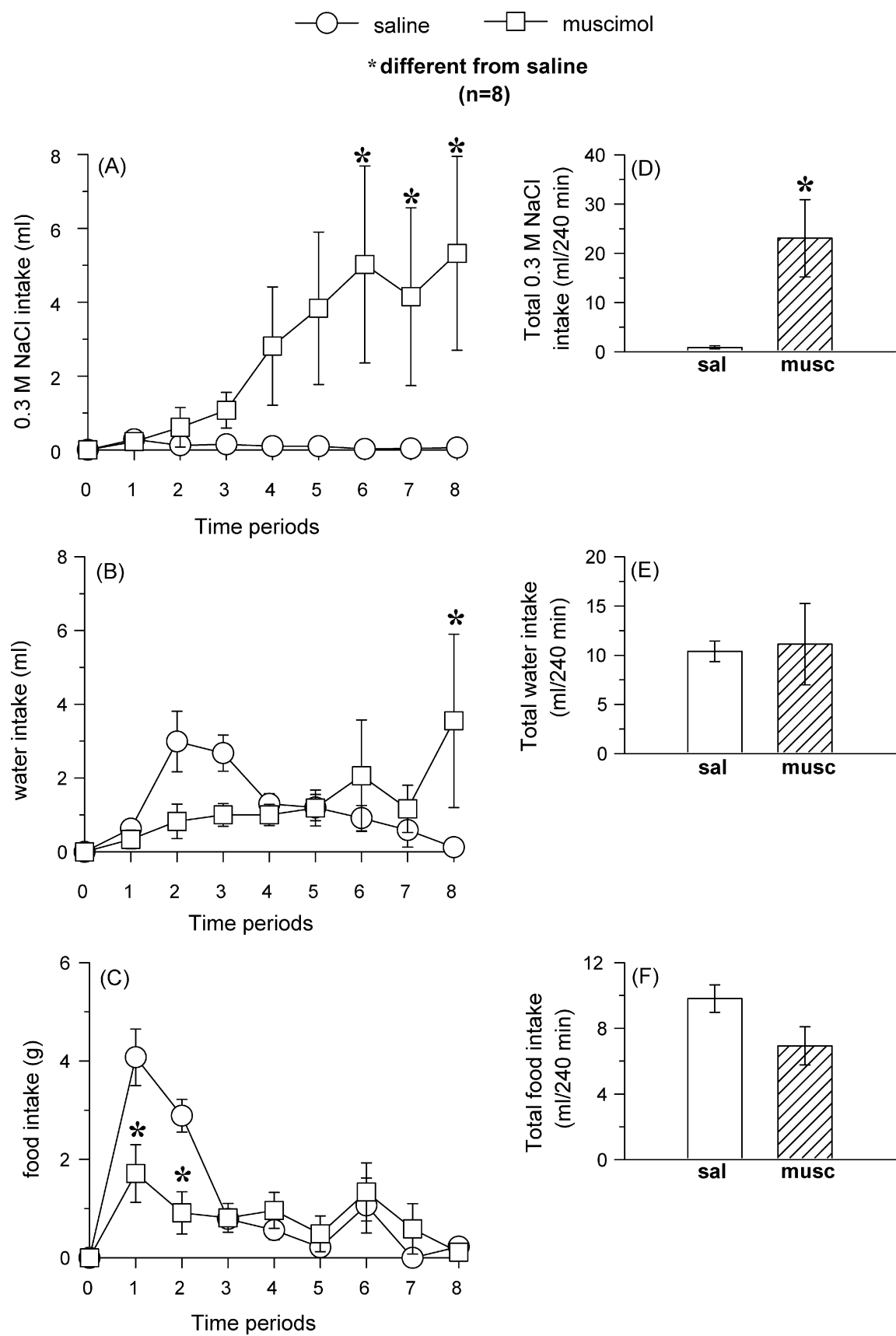

Fig. 4. Left panels: (A) $0.3 \mathrm{M} \mathrm{NaCl}$, (B) water and (C) food intake at different periods of test. Right panels: total (D) $0.3 \mathrm{M} \mathrm{NaCl}$, (E) water and (F) food intake during the whole test in $24 \mathrm{~h}$ food deprived rats that received bilateral injections of muscimol $(0.5 \mathrm{nmol} / 0.2 \mu \mathrm{l})$ or saline into the LPBN. Results are expressed as means \pm S.E.M.; $n$, number of rats; time periods: $1=0-30 \mathrm{~min}, 2=30-60 \mathrm{~min}, 3=60-90 \mathrm{~min}, 4=90-120 \mathrm{~min}, 5=120-150 \mathrm{~min}, 6=150-180 \mathrm{~min}, 7=180-210 \mathrm{~min}$ and $8=210-240 \mathrm{~min} ; \mathrm{sal}=$ saline; musc $=$ muscimol.

intake $[F(1,6)=1.9, p>0.05]$ (Fig. $6 \mathrm{~B})$ or $2 \%$ sucrose intake $[F(1,6)=0.6, p>0.05]$ (Fig. 6C). Muscimol into the LPBN increased the total intake of sodium (Fig. 6D), without changing the total intake of water (Fig. 6E) or $2 \%$ sucrose (Fig. 6F).

\section{Discussion}

The present results show that bilateral injections of muscimol into the LPBN produce dual effects on sodium depletioninduced sodium intake: an early inhibition (in the first $15 \mathrm{~min}$ of test) and a late facilitation of $0.3 \mathrm{M} \mathrm{NaCl}$ intake (from 30 to $120 \mathrm{~min}$ of test). Both effects of muscimol are abolished by previous injections of the $\mathrm{GABA}_{\mathrm{A}}$ receptor antagonist bicuculline, but not CGP 35348 (GABA $\mathrm{GA}_{\mathrm{B}}$ receptor antagonist) into the LPBN, suggesting that these effects on sodium intake depend on $\mathrm{GABA}_{\mathrm{A}}$ receptor activation in the LPBN. The blockade of $\mathrm{GABA}_{\mathrm{A}}$ or $\mathrm{GABA}_{\mathrm{B}}$ receptors with bilateral injections of bicuculline or CGP 35348, respectively, into the LPBN produces no change on sodium or water intake in sodium depleted rats, suggesting that GABAergic mechanisms in the LPBN do not 


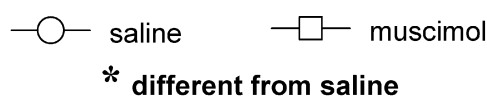

$(n=9)$
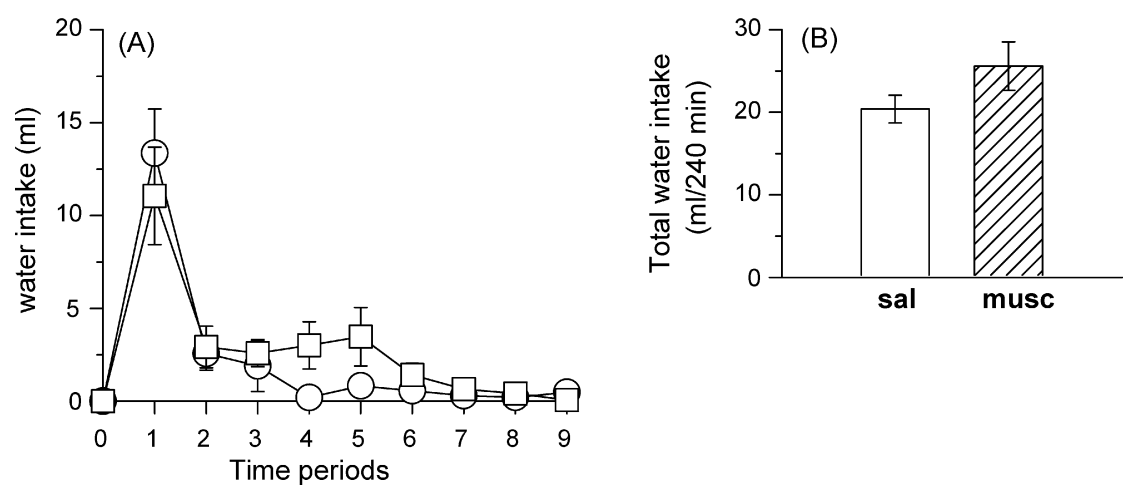

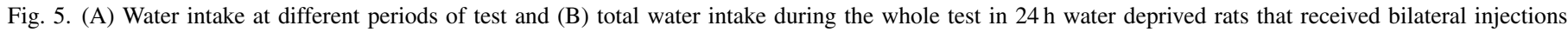

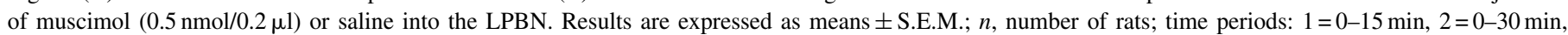
$3=30-60 \mathrm{~min}, 4=60-90 \mathrm{~min}, 5=90-120 \mathrm{~min}, 6=120-150 \mathrm{~min}, 7=150-180 \mathrm{~min}, 8=180-210 \mathrm{~min}$ and $9=210-240 \mathrm{~min}$; sal = saline; musc = muscimol.

tonically inhibit or facilitate these behaviors in sodium depleted rats.

Muscimol bilaterally injected into the LPBN induces a small ingestion of water (around $5 \mathrm{ml}$ ) in satiated rats [8]. In the present study, muscimol into the LPBN did not consistently increase water intake when $0.3 \mathrm{M} \mathrm{NaCl}$ and food or sucrose were simultaneously available. Water deprivation-induced water intake was also not significantly affected by muscimol into the LPBN. Therefore, it seems that water intake after muscimol injections into the LPBN in sodium depleted rats could be secondary to an increase in plasma osmolarity due to the excessive ingestion of hypertonic $\mathrm{NaCl}$. However, since muscimol induced a slight ingestion of water in satiated rats, it is not possible to discard that at least part of the intake could be a direct effect of GABAergic activation in the LPBN.

When besides $0.3 \mathrm{M} \mathrm{NaCl}$ and water, sodium depleted rats had also access to $2 \%$ sucrose solution, muscimol into the LPBN again produced significant dual effects on sodium intake and only a tendency to reduce sucrose intake in the first $15 \mathrm{~min}$ and to increase it from 60 to $90 \mathrm{~min}$ of test. In food deprived rats that had access to food, $0.3 \mathrm{M} \mathrm{NaCl}$ and water, muscimol into the LPBN significantly increased sodium intake as previously demonstrated in water-repleted normovolemic rats [8] and reduced food intake in the first $30 \mathrm{~min}$ of test. Therefore, although different ingestive behaviors (at least sodium and food intake) are inhibited by $\mathrm{GABA}_{\mathrm{A}}$ receptor activation in the LPBN, the facilitation of sodium intake in sodium depleted rats is not due to non-specific effect of $\mathrm{GABA}_{\mathrm{A}}$ activation of the LPBN on all ingestive behaviors.

It has been shown that GABAergic activation in different central areas increases sucrose solution intake $[4,18]$. The parabrachial nucleus also participates in the control of sucrose intake. Injection of midazolam (benzodiazepine receptor agonist) into the parabrachial nucleus increases 3\% sucrose consumption in satiated rats [16] and c-fos protein expression increases in the lateral and medial parabrachial nucleus after voluntary ingestion of sucrose by rats [40]. However, in sodium depleted rats, the present results show that $\mathrm{GABA}_{\mathrm{A}}$ receptor activation in the LPBN increases sodium intake with only a tendency to reduce sucrose intake in the first $15 \mathrm{~min}$ and increase it from 30 to $90 \mathrm{~min}$ of test.

Central GABAergic mechanisms and the PBN are also involved in the control of food intake [36,13,37,21,25,43,39]. The present results show that muscimol into the LPBN reduced $24 \mathrm{~h}$ food deprivation-induced food intake in the first $30 \mathrm{~min}$ of test. Taken together, the results on food and sucrose intake and water deprivation-induced water intake in rats injected with muscimol into the LPBN reinforce the proposal that the facilitatory effect of muscimol on sodium intake is not a result of general activation of ingestive behavior. On the other hand, the inhibitory effect of muscimol on food deprivationinduced food intake may suggest a non-specific inhibitory effect of muscimol on ingestive behavior, but the absence of inhibitory effects of muscimol on sucrose intake and on water intake in $24 \mathrm{~h}$ water deprived rats suggests that the early inhibitory effect of muscimol on sodium depletioninduced sodium intake is not secondary to any locomotor impairment.

At the end of $3 \mathrm{~h}$ of test, satiated and normovolemic rats [8] or rats previously submitted to sodium depletion (present results) ingest similar amount of $0.3 \mathrm{M} \mathrm{NaCl}$ after muscimol into the LPBN (around $40 \mathrm{ml}$ ). Hungry rats that have also food available ingested a little less of $0.3 \mathrm{M} \mathrm{NaCl}$ (around $25 \mathrm{ml}$ in $4 \mathrm{~h}$ ) perhaps due to the competition between the two behaviors, i.e. because the time rats have to spend ingesting food. Therefore, these results suggest that the facilitatory effect of muscimol on sodium intake is independent on the initial physiological state of the rats. In sodium depleted rats, muscimol induced an early inhibition (first $15 \mathrm{~min}$ ), however, from 30 to $120 \mathrm{~min}$ of test, muscimol into the LPBN increased $0.3 \mathrm{M} \mathrm{NaCl}$ intake and at the end of $3 \mathrm{~h}$ test the amount of sodium ingested is similar if rats were satiated or sodium depleted. It seems that the inhi- 


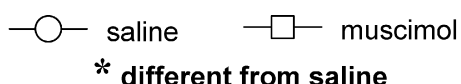

$(n=7)$
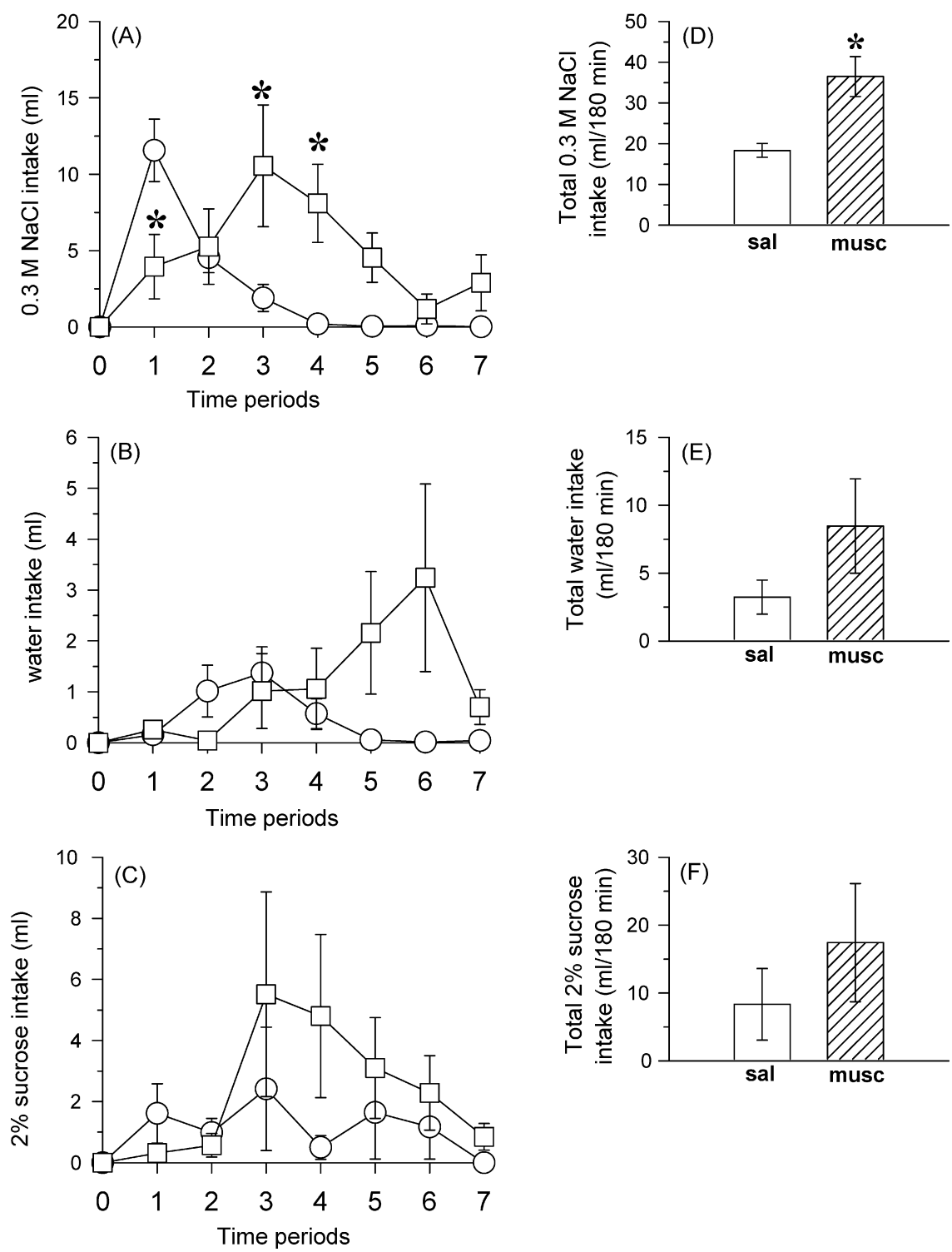

Fig. 6. Left panels: (A) $0.3 \mathrm{M} \mathrm{NaCl}$, (B) water and (C) $2 \%$ sucrose intake at different periods of test. Right panels: total (D) $0.3 \mathrm{M} \mathrm{NaCl}$, (E) water and (F) $2 \%$ sucrose intake during the whole test in $24 \mathrm{~h}$ sodium depleted rats that received bilateral injections of muscimol $(0.5 \mathrm{nmol} / 0.2 \mu \mathrm{l})$ or saline into the LPBN. Results are expressed as means \pm S.E.M.; $n$, number of rats; time periods: $1=0-15 \mathrm{~min}, 2=15-30 \mathrm{~min}, 3=30-60 \mathrm{~min}, 4=60-90 \mathrm{~min}, 5=90-120 \mathrm{~min}, 6=120-150 \mathrm{~min}$ and $7=150-180 \mathrm{~min} ; \mathrm{sal}=$ saline; musc $=$ muscimol.

bition and the facilitation of sodium intake by muscimol into the LPBN may also be related to the action of two different mechanisms in two different conditions. First an inhibition of sodium intake in a sodium depleted rat (first $15 \mathrm{~min}$ ) and then a facilitation of sodium intake in a non-depleted (or no longer sodium depleted) rat (from 30 to $120 \mathrm{~min}$ ). By this hypothesis, muscimol into the LPBN inhibits sodium intake if rats are sodium depleted. However as soon as rats had ingested sodium and water enough to recover from the depletion, muscimol into the LPBN start to induce more sodium intake similarly it does in satiated and normovolemic rats. It is important to note that not only sodium, but also food intake was inhibited at the same time by muscimol into the LPBN, suggesting a more general inhibition of ingestive behaviors. To produce this dual effect on sodium intake, immediately after the injection into the LPBN, muscimol may increase the action of LPBN inhibitory mechanisms, while late it blocks LPBN inhibitory mechanisms to facilitate sodium intake. Different studies have shown that GABAergic activation can produce dual effects (inhibitory and facilitatory). In the neonatal rat, GABA produces excitatory and inhibitory effects on the hippocampus network activity [22]. In addition, $\mathrm{GABA}_{\mathrm{A}}$ receptors have a dual action on the secretory process of melan- 
otrophs of Xenopus laevis: an inhibitory action associated with chloride channels and an excitatory signaling related direct or indirectly to AMPc production [19]. Studies have also showed that GABA has an excitatory (mediated possibly by $\mathrm{GABA}_{\mathrm{A}}$ receptors) and an inhibitory effect (mediated by $\mathrm{GABA}_{\mathrm{A}}$ and $\mathrm{GABA}_{\mathrm{B}}$ receptors) on the neurotransmission in the superficial gray layer [2].

Increases in arterial pressure may reduce sodium intake $[20,5,42,41]$ and muscimol into the LPBN produces a small increase on arterial pressure in satiated and normovolemic rats [8]. Therefore, if the same increase of arterial pressure occurs in sodium depleted rats, the early inhibition of sodium depletioninduced sodium intake by muscimol into the LPBN might also be related to the immediate increase of arterial pressure produced by the injections of muscimol. Although the increase in arterial pressure persists for at least $2 \mathrm{~h}$ after muscimol into the LPBN, pressure receptors may adapt later reducing the inhibitory signals which could allowed the late facilitatory effects of muscimol on sodium intake. Due to the long delay ( $30 \mathrm{~min}$ to $2 \mathrm{~h}$ ), the increase of sodium intake might be a secondary effect of muscimol into the LPBN and increases in renal excretion would be one possibility. However, muscimol into the LPBN produces non-significant effects on renal excretion in satiated rats [8], which suggests that sodium intake produced by muscimol into the LPBN is not a consequence of increases in renal excretion. Another question is if muscimol is still acting on $\mathrm{GABA}_{\mathrm{A}}$ receptors $1-2 \mathrm{~h}$ after the injection into the LPBN. To clarify this point, in a previous study in normovolemic rats [8], it was injected the $\mathrm{GABA}_{\mathrm{A}}$ receptor antagonist bicuculline into the LPBN $1 \mathrm{~h}$ after muscimol and the increase of sodium intake was completely blocked which suggests that muscimol produces a long lasting activation of $\mathrm{LPBN} \mathrm{GABA}_{\mathrm{A}}$ receptors and this is essential to increase sodium ingestion.

Although the activation of $\mathrm{GABA}_{\mathrm{A}}$ receptors in the LPBN strongly affects sodium intake, the blockade of $\mathrm{GABA}_{\mathrm{A}}$ or $\mathrm{GABA}_{\mathrm{B}}$ receptors of the LPBN with bicuculline or CGP 35348 did not affect sodium depletion-induced sodium intake, which suggests that activation of LPBN GABAergic mechanisms is not an essential step for sodium intake induced by sodium depletion. Therefore the physiological role of LPBN GABAergic mechanisms in the control of sodium intake is still not completely clear. Although activation of GABAergic mechanisms is not necessary for sodium depletion-induced sodium intake, they may modulate sodium intake in a different situation not yet tested like mineralocorticoid-induced sodium intake or the facilitation of sodium intake by hypotension. Muscimol into the LPBN in normotensive rats increases arterial pressure [8], which suggests that GABAergic mechanisms of the LPBN may act physiologically to counterbalance hypotension.

In summary, although $\mathrm{GABA}_{\mathrm{A}}$ receptor activation in the LPBN produces an early inhibition and a late facilitation of sodium depletion-induced sodium intake, $\mathrm{GABA}_{\mathrm{A}}$ receptors in the LPBN are not tonically involved in the control of sodium depletion-induced sodium intake. Both sodium and food intakes were inhibited by muscimol into the LPBN, but only sodium intake was increased later; and sucrose intake was hardly altered. The results suggest that the facilitation of sodium intake in sodium depleted rats is not due to non-specific effect of $\mathrm{GABA}_{\mathrm{A}}$ receptor activation of the LPBN on all ingestive behaviors.

\section{Acknowledgements}

We thank Reginaldo C. Queiróz, Sílvia Fóglia and Silas Pereira Barbosa for expert technical assistance, Silvana A.D. Malavolta for secretarial assistance and Ana L.V. de Oliveira for animal care. This research was supported by public funding from FAPESP, CNPq and CAPES and is part of the activities developed by Lisandra B. de Oliveira to obtain a $\mathrm{PhD}$ degree at the Graduate Program in Physiological Sciences at the Federal University of São Carlos (UFSCar), SP, Brazil (Graduate program from UFSCar associate with UNESP).

\section{References}

[1] M. Abe, T. Tokunaga, K. Yamada, T. Furukawa, Gamma-aminobutyric acid and taurine antagonize the central effects of angiotensin II and renin on the intake of water and salt and on blood pressure in rats, Neuropharmacology 27 (1988) 309-318.

[2] T. Arakawa, Y. Okada, Excitatory and inhibitory action of GABA in synaptic transmission in slices of guinea pig superior colliculus, Eur. J. Pharmacol. 158 (1988) 217-224.

[3] T. Araki, H. Kiyama, M. Tohyama, The GABA A receptor gamma 1 subunit is expressed by distinct neuronal populations, Mol. Brain Res. 15 (1992) $121-132$.

[4] A.M. Basso, A.E. Kelley, Feeding induced by GABA(A) receptor stimulation within the nucleus accumbens shell: regional mapping and characterization of macronutrient and taste preference, Behav. Neurosci. 113 (1999) 324-336.

[5] E. Bott, D.A. Denton, S. Weller, The effect of angiotensin II infusion, renal hypertension and nephrectomy on salt appetite of sodium-deficient sheep, Aust. J. Exp. Biol. Med. Sci. 45 (1967) 595-612.

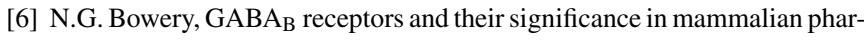
macology, Trends Pharmacol. Sci. 10 (1989) 401-407.

[7] N.G. Bowery, A.L. Hudson, G.W. Price, GABA A $_{A}$ and $G_{B B}$ B receptor binding site distribution in the rat central nervous system, Neuroscience 20 (1987) 365-383.

[8] J.C. Callera, L.B. Oliveira, S.P. Barbosa, D.S.A. Colombari, L.A. De Luca Jr., J.V. Menani, GABA(A) receptor activation in the lateral parabrachial nucleus induces water and hypertonic $\mathrm{NaCl}$ intake, Neuroscience 134 (2005) 725-735.

[9] M.J. Christie, R.A. North, Agonists at mu-opioid, $\mathbf{M}_{2}$-muscarinic and $\mathrm{GABA}_{\mathrm{B}}$ receptors increase the same potassium conductance in rat lateral parabrachial neurones, Br. J. Pharmacol. 95 (1988) 896-902.

[10] D.S.A. Colombari, J.V. Menani, A.K. Johnson, Forebrain angiotensin type 1 receptors and parabrachial serotonin in the control of $\mathrm{NaCl}$ and water intake, Am. J. Physiol. 271 (1996) R1470-R1476.

[11] J.I.F. De Gobbi, L.A. De Luca Jr., J.V. Menani, Serotonergic mechanisms of the lateral parabrachial nucleus on DOCA-induced sodium intake, Brain Res. 880 (2000) 131-138.

[12] L.A. De Luca Jr., S.P. Barbosa, J.V. Menani, Brain serotonin blockade and paradoxical salt intake in rats, Neuroscience 121 (2003) 1055-1061.

[13] I.S. Ebenezer, Intraperitoneal administration of baclofen increases consuption of both solid and liquid diets in rats, Eur. J. Pharmacol. 273 (1995) 183-185.

[14] C.E. Fulwiler, C.B. Saper, Subnuclear organization of the efferent connections of the parabrachial nucleus in the rat, Brain Res. Rev. 7 (1984) 229-259.

[15] A. Guthmann, J.M. Fritschy, O.P. Ottersen, R. Torp, H. Herbert, GABA, GABA transporters, GABA(A) receptor subunits, and GAD mRNAs in the 
rat parabrachial and Kolliker-Fuse nuclei, J. Comp. Neurol. 400 (1998) 229-243.

[16] S. Higgs, S.J. Cooper, Hyperphagia induced by direct administration of midazolam into the parabrachial nucleus of the rat, Eur. J. Pharmacol. 313 (1996) 1-9.

[17] T. Hironaka, Y. Morita, S. Hagihira, E. Tateno, H. Kita, M. Tohyama, Localization of GABAA-receptor alpha 1 subunit mRNA-containing neurons in the lower brainstem of the rat, Mol. Brain Res. 7 (1990) 335-345.

[18] C.W. Hodge, M. Haraguchi, A.M. Chappelle, H.H. Samson, Effects of ventral tegmental microinjections of the GABAA agonist muscimol on self-administration of ethanol and sucrose, Pharmacol. Biochem. Behav. 53 (1996) 971-977.

[19] B.G. Jenks, H.P. de Koning, K. Valentijn, E.W. Roubos, Dual action of GABAA receptors in the secretory process of melanotrophs of Xenopus laevis, Neuroendocrinology 58 (1993) 80-85.

[20] A.K. Johnson, R.L. Thunhorst, The neuroendocrinology of thirst and salt appetite: visceral sensory signals and mechanisms of central integration Front. Neuroendocrinol. 18 (1997) 292-353.

[21] K.M. Kendrick, M.R. Hinton, B.A. Baldwin, GABA release in the zona incerta of the sheep in response to the sight and ingestion of food and salt, Brain Res. 550 (1991) 165-168.

[22] I. Khalilov, V. Dzhala, Y. Ben-Ari, R. Khazipov, Dual role of GABA in the neonatal rat hippocampus, Dev. Neurosci. 21 (1999) 310-319.

[23] M.A. Klitenick, D. Wirtshafter, Comparative studies of the ingestive behaviors produced by microinjections of muscimol into the midbrain raphe nuclei of the ventral tegmental area of the rat, Life Sci. 42 (1988) 775-782.

[24] M.A. Klitenick, D. Wirtshafter, Elicitation of feeding, drinking, and gnawing following microinjections of muscimol into the median raphe nucleus of rats, Behav. Neural Biol. 51 (1989) 436-441.

[25] M.D. Lee, V.J. Aloyo, S.J. Fluharty, K.J. Simansky, Infusion of the serotonin1B (5-HT1B) agonist CP-93, 129 into the parabrachial nucleus potently and selectively reduces food intake in rats, Psychopharmacology (Berl.) 136 (1998) 304-307.

[26] M.P. Meeley, M.D. Underwood, W.T. Talman, D.J. Reis, Content and in vitro release of endogenous amino acids in the area of the solitary tract of the rat, J. Neurochem. 53 (1989) 1807-1817.

[27] J.V. Menani, S.P. Barbosa, M.J. McKinley, J.D. Wade, L.A. De Luca Jr., Serotonergic mechanism of the lateral parabrachial nucleus and relaxininduced sodium intake, Brain Res. 1030 (2004) 74-80.

[28] J.V. Menani, D.S.A. Colombari, T.G. Beltz, R.L. Thunhorst, A.K. Johnson, Salt appetite: interaction of forebrain angiotensinergic and hindbrain serotonergic mechanisms, Brain Res. 801 (1998) 29-35.

[29] J.V. Menani, L.A. De Luca Jr., A.K. Johnson, Lateral parabrachial nucleus serotonergic mechanisms and salt appetite induced by sodium depletion, Am. J. Physiol. 274 (1998) R555-R560.
[30] J.V. Menani, A.K. Johnson, Cholecystokinin actions in the parabrachial nucleus: effects on thirst and salt appetite, Am. J. Physiol. 275 (1998) R1431-R1437.

[31] J.V. Menani, R.L. Thunhorst, A.K. Johnson, Lateral parabrachial nucleus and serotonergic mechanisms in the control of salt appetite in rats, Am. J. Physiol. 270 (1996) R162-R168.

[32] F.J. Minano, M.S. Meneres Sancho, M. Sancibrian, P. Salinas, R.D. Myers, GABAA receptors in the amygdala: role in feeding in fasted and satiated rats, Brain Res. 586 (1992) 104-110.

[33] L.E. Ohman, A.K. Johnson, Lesions in the lateral parabrachial nucleus enhance drinking to angiotensin II and isoproterenol, Am. J. Physiol. 251 (1986) R504-R509.

[34] L.E. Ohman, A.K. Johnson, Role of the lateral parabrachial nucleus in the inhibition of water intake produced by right atrial stretch, Brain Res. 695 (1995) 275-282.

[35] T.M. Saleh, D.F. Cechetto, Neurotransmitters in the parabrachial nucleus mediating visceral imput to the thalamus in rats, Am. J. Physiol. 266 (1994) R1287-R1296.

[36] A. Sclafani, A.V. Azzara, K. Touzani, P.S. Grigson, R. Norgren, Parabrachial nucleus lesions block taste and attenuate flavor preference and aversion conditioning in rats, Behav. Neurosci. 115 (2001) 920933.

[37] K.J. Simansky, D.M. Nicklous, Parabrachial infusion of D-fenfluramine reduces food intake blockade by the 5-HT(1B) antagonist SB-216641, Pharmacol. Biochem. Behav. 71 (2002) 681-690.

[38] A.H. Soderpalm, K.C. Berridge, The hedonic impact and intake of food are increased by midazolam microinjection in the parabrachial nucleus, Brain Res. 877 (2000) 288-297.

[39] T.R. Stratford, A.E. Kelley, GABA in the nucleus accumbens shell participates in the central regulation of feeding behavior, J. Neurosci. 17 (1997) 4434-4440.

[40] C. Streefland, E. Farkas, F.W. Maes, B. Bohus, C-fos expression in the brainstem after voluntary ingestion of sucrose in the rat, Neurobiology 4 (1996) 85-102.

[41] R.L. Thunhorst, S.J. Lewis, A.K. Johnson, Effects of sinoaortic baroreceptor denervation on depletion-induced salt appetite, Am. J. Physiol. 267 (1994) R1043-R1049.

[42] E. Toth, J. Stelfox, S. Kaufman, Cardiac control of salt appetite, Am. J. Physiol. 252 (1987) R925-R929.

[43] R. Trifunovic, S. Reilly, Medial versus lateral parabrachial nucleus lesions in the rat: effects of cholecystokinin- and D-fenfluramine-induced anorexia, Brain Res. 894 (2001) 288-296.

[44] T. Unger, F. Bles, D. Ganten, R.E. Lang, R. Rettig, N.A. Schwab, GABAergic stimulation inhibits central actions of angiotensin II: pressor responses, drinking and release of vasopressin, Eur. J. Pharmacol. 90 (1983) 1-9. 